\title{
MENINGKATKAN AKTIVITAS DAN HASIL BELAJAR SISWA PADA MATERI BARISAN DAN DERET DENGAN MENGGUNAKAN MODEL PROBLEM BASED INSTRUCTION (PBI) DI KELAS IX B SMPN 3 PARINGIN TAHUN PELAJARAN 2013/2014
}

\author{
Saudah, Agni Danaryanti
}

\begin{abstract}
Abstrak
Telah dilakukan penelitian tentang penerapan model pembelajaran Problem Based Instruction (PBI) pada materi barisan dan deret. Tujuan penelitian ini adalah untuk mengetahui peningkatkan aktivitas dan hasil belajar matematika khususnya pada materi barisan dan deret melalui model pembelajaran Problem Based Instruction (PBI).

Penelitian ini menggunakan rancangan penelitian tindakan kelas dengan 2 siklus. Masing-masing siklus terdiri dari tahapan perencanaan, pelaksanaan tindakan, observasi, dan refleksi. Subjek penelitian adalah siswa kelas IX B SMPN 3 Paringin yang terdiri dari 16 siswa. Instumen penelitian berupa lembar observasi aktivitas belajar siswa dan tes tertulis.

Hasil penelitian menyatakan bahwa dengan model pembelajaran Problem Based Instruction (PBI) dapat (1) Meningkatkan aktivitas belajar siswa mencapai kreteria aktif dari siklus 1 ke siklus 2 dengan kenaikan rata-rata tiap asfek sebesar 14,4\% (2) Meningkatkan hasil belajar siswa dari siklus 1 ke siklus 2 dengan ketuntasan individual dari 9 siswa menjadi 14 siswa dan ketuntasan klasikal dari $56 \%$ menjadi $88 \%$ dengan kenaikan sebesar 32\%. Hal ini berarti dengan model pembelajaran Problem Based Intruction (PBI) dapat meningkatkan aktivitas dan hasil belajar siswa.
\end{abstract}

Kata Kunci: Problem Based Instruction, aktivitas dan hasil belajar, barisan dan deret.

\section{Pendahuluan}

Pengajaran matematika sering ditemui di sekolah-sekolah bahwa sebagian besar diberikan secara klasikal yang melalui metode ceramah tanpa banyak melihat kemungkinan penerapan metode lain yang sesuai dengan jenis materi, bahan dan alat yang tersedia. Siswa kurang berminat mengikuti proses pembelajaran yang dilakukan oleh guru, membuat siswa 
merasa bosan dan tidak tertarik dalam mengikuti kegiatan belajar mengajar sehingga tidak ada motivasi dari dalam diri siswa untuk memahami apa yang diajarkan oleh guru. Peristiwa yang sangat menonjol adalah siswa kurang kreatif, kurang terlibat langsung, dan pertanyaan jarang muncul dari siswa ketika proses pembelajaran. Pentingnya pembelajaran matematika dalam kehidupan sehari-hari membuat siswa termotivasi untuk belajar matematika.

Berdasarkan pengalaman mengajar matematika di kelas IX SMPN 3 Paringin, barisan dan deret adalah salah satu materi matematika yang dianggap cukup sulit oleh siswa. Hal ini dapat dilihat dari hasil ulangan harian maupun ulangan umum pada materi barisan dan deret. Untuk ulangan harian dan ulangan umum semester hasil yang dicapai siswa ratarata masih dibawah standar ketuntasan minimal yang sudah ditetapkan yakni 70 dan hanya mampu mencapai ketuntasan klasikal sebesar $48 \%$.

Rendahnya nilai siswa dalam pembelajaran materi barisan dan deret antara lain disebabkan; (a) Siswa tidak aktif bertanya ketika proses pembelajaran berlangsung; (b) kurangnya kerjasama diantara siswa dalam kelompok belajar; (c) siswa kurang tanggap dalam menyimpulkan masalah kedalam model matematika yang berkaitan dengan konsep barisan dan deret; (d) guru belum menggunakan metode dan model pembelajaran yang tepat untuk mengatasi rendahnya keterlibatan siswa dalam proses pembelajaran.

Pada materi barisan dan deret mempunyai ciri yaitu selalu beracuan pada masalah kehidupan sehari-hari. Langkah pertama penyelesaian masalah pada konsep ini adalah mengubah masalah tersebut ke dalam model matematika. Karena konsep barisan dan deret berdasarkan masalah maka, pembelajaran yang tepat menggunakan model PBI (Problem Based Instruction). Dalam model pembelajaran PBI memuat sintak-sintak yang menuntut siswa bisa menelaah masalah dan memecahkannya serta dapat membuat suatu kesimpulan sendiri atau secara berkelompok yang dapat membangun keaktifan siswa dalam proses pembelajaran dikelas. 
Meningkatkan Aktivitas Dan Hasil Belajar Siswa Pada Materi Barisan Dan Deret Dengan Menggunakan Model Problem Based Instruction (PBI) Di Kelas IX B SMPN 3 Paringin Tahun Pelajaran 2013/2014

Menurut Suyatno (2009:58) PBI adalah proses pembelajaran yang titik awal pembelajaran berdasarkan masalah pada kehidupan nyata lalu dari masalah ini dirangsang untuk mempelajari masalah berdasarkan pengetahuan dan pengalaman yang telah mereka punyai sebelumnya ( $p r i o r$ knowledge) sehingga dari prior knowledge ini terbentuk pengetahuan dan pengalaman baru.

Sintaks pengajaran model Problem Based Instruction (PBI) menurut Trianto (2008:71-72) sebagai berikut:

1. Guru menjelaskan tujuan pembelajaran. Menjelaskan logistik yang dibutuhkan,mengajukan fenomena atau demonstrasi atau cerita untuk memunculkan masalah,memotivasi siswa ikut terlibat dalam aktivitas pemecahan masalah yang dipilih.

2. Guru membantu siswa mendifinisikan dan mengorganisasikan tugas belajar yang berhubungan dengan masalah tersebut (menetapkan topik, tugas, jadwal, dan lain-lain).

3. Guru mendorong siswa untuk mengumpulkan informasi yang sesuai, melaksanakan eksperimen, untuk mendapatkan penjelasan dan pemecahan masalah, pengumpulan data, hipotesa, dan pemecahan masalah.

4. Guru membantu siswa dalam merencanakan dan menyiapkan karya yang sesuai seperti laporan dan membantu mereka berbagi tugas dengan temannya.

5. Guru membantu siswa untuk melakukan refleksi atau evaluasi terhadap penyelidikan mereka dan proses yang mereka gunakan.

Penelitian tidakan kelas ini bertujuan untuk: (1) meningkatkan aktivitas belajar siswa melalui model Problem Based Instruction (PBI), (2) meningkatkan hasil belajar siswa melalui model pembelajaran Problem Based Instruction (PBI). Melalui model pembelajaran PBI dapat membuat siswa lebih terlibat dalam proses pembelajaran dan aktivitas siswa lebih meningkat dan melatih siswa agar mampu mengungkapkan gagasan atau 
saran dalam penyelesaian masalah yang berkaitan dengan model matematika, khususnya pada materi barisan dan deret.

Dalam penelitian ini diajukan hipotesis penelitian yang berbunyi “ Jika model pembelajaran Problem Based Instruction (PBI) diterapkan, maka aktivitas dan hasil belajar siswa kelas IX B SMPN 3 Paringin pada materi barisan dan deret dapat meningkat”.

\section{Metode Penelitian}

Rancangan penelitian ini berupa penelitian tindakan kelas, dengan subjek siswa kelas IX B SMPN 3 Paringin Kecamatan Paringin Kabupaten Balangan Tahun Pelajaran 2013/2014 yang berjumlah 16 orang. Desain penelitian terdiri dari empat tahapan yaitu perencanaan, pelaksanaan tindakan, observasi dan evaluasi, serta refleksi yang diikuti perencanaan ulang.

Penelitian Tindakan Kelas ini terdiri dari 2 siklus. Siklus pertama terdiri dari 2 kali pertemuan dengan 1 kali pertemuan evaluasi dan siklus kedua terdiri dari 2 kali pertemuan dengan 1 kali pertemuan evaluasi. Dalam hal ini setiap pertemuan dengan durasi waktu $2 \times 40$ menit.

Instrumen penelitian ini meliputi (1) pengamatan aktivitas belajar siswa (2) tes hasil belajar. Data penelitian yang berupa hasil belajar siswa dalam pembelajaran di peroleh dengan cara tes pengusaan materi setelah berakhir setiap siklus, sedangkan aktivitas belajar siswa di peroleh dengan menggunakan lembar observasi yang di isi oleh observer yang telah ditentukan oleh Yayasan Adaro Bangun Negeri.

Hasil penelitian di analisis secara deskriptif kualitatif dalam bentuk persentase untuk melihat aktivitas belajar siswa dalam proses pembelajaran, sedangkan tes hasil belajar dianalisis dengan memberikan skor setiap jawaban, untuk menentukan ketuntasan belajar secara individual dan klasikal.

Penelitian ini dikatakan berhasil jika hasil belajar siswa secara individu memperoleh nilai $\geq 70$ dan secara klasikal $85 \%$ hasil belajarnya 
Meningkatkan Aktivitas Dan Hasil Belajar Siswa Pada Materi Barisan Dan Deret Dengan Menggunakan Model Problem Based Instruction (PBI) Di Kelas IX B SMPN 3 Paringin Tahun Pelajaran 2013/2014

tuntas dan terjadi peningkatan aktivitas belajar siswa dari siklus 1 ke siklus berikutnya.

\section{Hasil Penelitian}

\section{Hasil Penelitian Siklus 1}

\section{a. Aktivitas belajar siswa dalam proses pembelajaran}

Hasil observasi aktivitas belajar siswa siklus I selama proses pembelajaran dengan menggunakan model pembelajaran Problem Based Instruction (PBI) dapat dilihat pada tabel berikut:

Tabel 1. Hasil Observasi Aktivitas Siswa Siklus I

\begin{tabular}{|c|c|c|c|c|c|}
\hline \multirow{3}{*}{ No } & \multirow{3}{*}{ Aspek yang diamati } & \multicolumn{2}{|c|}{ Pertemuan } & \multirow{2}{*}{ Rata-rata } & \multirow{2}{*}{ Kriteria } \\
\hline & & 1 & 2 & & \\
\hline & & $\%$ & $\%$ & $\%$ & \\
\hline 1. & $\begin{array}{l}\text { Siswa secara proaktif } \\
\text { men jawab pertanyaan }\end{array}$ & 45 & 60 & 53 & $\begin{array}{l}\text { Cukup } \\
\text { aktif }\end{array}$ \\
\hline 2. & $\begin{array}{l}\text { Siswa mampu } \\
\text { mengemukakan } \\
\text { pendapat atau saran }\end{array}$ & 59 & 69 & 64 & $\begin{array}{l}\text { Cukup } \\
\text { aktif }\end{array}$ \\
\hline 3. & $\begin{array}{l}\text { Saran yang dikemukakan } \\
\text { siswa berkaitan dengan } \\
\text { masalah yang diajukan }\end{array}$ & 55 & 67 & 61 & $\begin{array}{l}\text { Cukup } \\
\text { aktif }\end{array}$ \\
\hline 4. & $\begin{array}{l}\text { Siswa proaktif } \\
\text { melakukan percobaan } \\
\text { untuk menjawab LKK }\end{array}$ & 64 & 70 & 67 & Aktif \\
\hline 5. & $\begin{array}{ll}\text { Siswa mau dan mampu } \\
\text { berdiskusi } & \text { dengan } \\
\text { kelompok nya } & \end{array}$ & 61 & 80 & 70 & Aktif \\
\hline 6. & \begin{tabular}{lrr} 
Siswa & \multicolumn{2}{c}{ menyelesaikan } \\
tugas sesuai & dengan \\
waktu yang & telah \\
ditentukan & \\
\end{tabular} & 70,3 & 80 & 75 & Aktif \\
\hline 7. & $\begin{array}{l}\text { Siswa berani } \\
\text { mempresentasi kan hasil } \\
\text { kerja kelompoknya }\end{array}$ & 59,3 & 69 & 64 & $\begin{array}{l}\text { Cukup } \\
\text { aktif }\end{array}$ \\
\hline
\end{tabular}

Aktivitas belajar siswa pada siklus pertama masih terdapat 4 aspek pada kriteria cukup aktif. Sedangkan pada 3 aspek yang lainnya sudah mencapai kriteria aktif. Diharapkan pada siklus 2 
aktivitas belajar siswa di semua aspek dapat meningkat menjadi aktif atau sangat aktif.

b. Hasil belajar siswa

Hasil belajar siswa selama proses pembelajaran dengan model pembelajaran Problem Based Instruction (PBI) adalah sebagai berikut :

Tabel 2. Hasil Belajar Siswa Siklus I

\begin{tabular}{|l|l|c|c|c|}
\hline No & \multicolumn{1}{|c|}{$\begin{array}{c}\text { Ketuntasan } \\
\text { Individu }\end{array}$} & $\begin{array}{c}\text { Jumlah } \\
\text { Siswa }\end{array}$ & Persentasi & $\begin{array}{c}\text { Ketuntasan } \\
\text { Klasikal }\end{array}$ \\
\hline 1. & Siswa Tuntas & 9 & $56 \%$ & \multirow{2}{*}{ Tidak tuntas } \\
\cline { 1 - 4 } 2. & Siswa Tidak Tuntas & 7 & $44 \%$ & \\
\hline
\end{tabular}

Pada tabel 2 di atas menunjukkan bahwa hasil belajar siswa pada siklus I diperoleh nilai ketuntasan belajar hanya 56\% atau hanya ada 9 siswa dari 16 siswa yang tuntas belajar. Hal tersebut menunjukkan bahwa pada siklus I secara klasikal belum mencapai ketuntasan belajar, karena siswa yang memperoleh nilai $\geq 70$ hanya sebesar 56\%. Hal ini menunjukkan bahwa ketuntasan klasikal masih belum mencapai batas yang ditetapkan yaitu $\geq 85 \%$.

\section{Hasil Penelitian siklus 2}

a. Aktivitas belajar siswa dalam proses pembelajaran

Hasil observasi aktivitas belajar siswa siklus II selama proses pembelajaran dengan menggunakan model pembelajaran Problem Based Instruction (PBI) dapat dilihat pada tabel berikut :

Tabel 3. Hasil Observasi Aktivitas Siswa Siklus II

\begin{tabular}{|c|l|c|c|c|c|}
\hline \multirow{2}{*}{ No } & \multirow{2}{*}{ Aspek yang diamati } & \multicolumn{2}{|c|}{ Pertemuan } & \multirow{2}{*}{ Rata-rata } & Kriteria \\
\cline { 3 - 5 } & & 1 & 2 & & \\
\cline { 3 - 6 } & & $\%$ & $\%$ & \\
\hline 1. & $\begin{array}{l}\text { Siswa secara proaktif } \\
\text { menjawab pertanyaan }\end{array}$ & 78 & 83 & 81 & Aktif \\
\hline 2. & Siswa mampu & 72 & 80 & 76 & Aktif \\
\hline
\end{tabular}


Meningkatkan Aktivitas Dan Hasil Belajar Siswa Pada Materi Barisan Dan Deret Dengan Menggunakan Model Problem Based Instruction (PBI) Di Kelas IX B SMPN 3 Paringin Tahun Pelajaran 2013/2014

\begin{tabular}{|c|c|c|c|c|c|}
\hline & $\begin{array}{l}\text { mengemukakan pendapat } \\
\text { atau saran }\end{array}$ & & & & \\
\hline 3. & $\begin{array}{l}\text { Saran yang dikemukakan } \\
\text { siswa berkaitan dengan } \\
\text { masalah yang diajukan }\end{array}$ & 75 & 84 & 80 & Aktif \\
\hline 4. & $\begin{array}{l}\text { Siswa proaktif melakukan } \\
\text { percobaan untuk } \\
\text { menjawab LKK }\end{array}$ & 89 & 81 & 85 & Aktif \\
\hline 5. & $\begin{array}{ll}\text { Siswa mau dan mampu } \\
\text { berdiskusi } & \text { dengan } \\
\text { kelompoknya } & \\
\end{array}$ & 80 & 83 & 81 & Aktif \\
\hline 6. & \begin{tabular}{lrr} 
Siswa & \multicolumn{2}{c}{ menyelesaikan } \\
tugas sesuai & dengan \\
waktu yang & telah \\
ditentukan & \\
\end{tabular} & 78 & 81 & 80 & Aktif \\
\hline 7. & $\begin{array}{lr}\text { Siswa } & \text { berani } \\
\text { mempresentasikan } & \text { hasil } \\
\text { kerja kelompoknya } & \end{array}$ & 70 & 81 & 76 & Aktif \\
\hline
\end{tabular}

Dari tabel di atas dapat diketahui bahwa pada kegiatan siklus II ini dari setiap kegiatan persentase aspek yang diamati semakin meningkat dan persentase rata-rata aspek yang di amati pada siklus II mengalami peningkatan dari pada siklus I. Hal ini terbukti ada 4 aspek pada siklus I mengalami peningkatan yaitu pada aspek satu, dua, tiga dan tujuh yang mana pada siklus I masih mencapai kriteria kurang aktif, sehingga pada siklus II empat aspek tersebut mencapai pada kriteria aktif, sehingga terlihat semua aktivitas belajar siswa mencapai kriteria aktif.

\section{b. Hasil belajar siswa}

Hasil belajar siswa selama proses pembelajaran dengan model pembelajaran Problem Based Instruction (PBI) adalah sebagai berikut :

Tabel 4. Hasil Belajar Siswa Siklus II

\begin{tabular}{|l|l|c|c|c|}
\hline No. & $\begin{array}{l}\text { Ketuntasan } \\
\text { Individu }\end{array}$ & $\begin{array}{l}\text { Jumlah } \\
\text { Siswa }\end{array}$ & Persentasi & $\begin{array}{l}\text { Ketuntasan } \\
\text { Klasikal }\end{array}$ \\
\hline 1. & Siswa Tuntas & 14 & $88 \%$ & \multirow{2}{*}{ Tuntas } \\
\cline { 1 - 4 } 2. & $\begin{array}{l}\text { Siswa Tidak } \\
\text { Tuntas }\end{array}$ & 2 & $12 \%$ & \\
\hline
\end{tabular}


Dari tabel di atas terlihat bahwa dari jumlah 16 siswa, siswa yang tuntas 14 orang dengan angka persentase yaitu $88 \%$ dan siswa yang tidak tuntas hanya 2 orang dengan angka persentase $12 \%$ dan memiliki nilai rata-rata 75,3 . Hal ini menunjukkan bahwa kelas tersebut tuntas secara klasikal karena lebih dari 85\% siswa di kelas mencapai skor $\geq 70$ dan nilai rata-rata mencapai kualifikasi baik.

\section{Pembahasan}

Berdasarkan hasil evaluasi terkait perkembangan Aktivitas belajar dicapai siswa dari siklus I ke siklus ke II yang dapat dilihat pada tabel berikut ini :

Tabel 5. Hasil Observasi Aktivitas Siswa Siklus I dan II

\begin{tabular}{|c|c|c|c|c|}
\hline \multirow{3}{*}{ No } & \multirow{3}{*}{ Aspek yang diamati } & \multicolumn{2}{|c|}{ Siklus } & \multirow[b]{2}{*}{ Peningkatan } \\
\hline & & $\begin{array}{l}\text { Rata- } \\
\text { rata I }\end{array}$ & $\begin{array}{l}\text { Rata- } \\
\text { rata II }\end{array}$ & \\
\hline & & $\%$ & $\%$ & $\%$ \\
\hline 1. & $\begin{array}{l}\text { Siswa secara proaktif menjawab } \\
\text { pertanyaan dari guru }\end{array}$ & 53 & 81 & 24 \\
\hline 2. & $\begin{array}{l}\text { Siswa mampu mengemukakan } \\
\text { pendapat atau saran }\end{array}$ & 64 & 76 & 12 \\
\hline 3. & \begin{tabular}{lll} 
Saran & yang & \multicolumn{2}{c}{ dikemukakan } \\
berkaitan & dengan \\
diajukan & & \\
\end{tabular} & 61 & 80 & 19 \\
\hline 4. & $\begin{array}{l}\text { Siswa proaktif melakukan } \\
\text { percobaan untuk menjawab LKK }\end{array}$ & 67 & 85 & 18 \\
\hline 5. & $\begin{array}{l}\text { Siswa mau dan mampu berdiskusi } \\
\text { dengan kelompoknya }\end{array}$ & 70 & 81 & 11 \\
\hline 6. & $\begin{array}{l}\text { Siswa menyelesaikan tugas sesuai } \\
\text { dengan waktu yang telah } \\
\text { ditentukan }\end{array}$ & 75 & 80 & 5 \\
\hline 7. & $\begin{array}{l}\text { Siswa berani mempresentasikan } \\
\text { hasil kerja kelompoknya }\end{array}$ & 64 & 76 & 12 \\
\hline \multicolumn{4}{|c|}{ Rata-rata } & 14,4 \\
\hline
\end{tabular}

Berdasarkan tabel tentang perkembangan aktivitas belajar siswa di atas, menunjukkan terjadi peningkatan aktivitas belajar siswa. Dalam hal ini 
Meningkatkan Aktivitas Dan Hasil Belajar Siswa Pada Materi Barisan Dan Deret Dengan Menggunakan Model Problem Based Instruction (PBI) Di Kelas IX B SMPN 3 Paringin Tahun Pelajaran 2013/2014

rata-rata peningkatan aktivitas belajar siswa dalam setiap aspek sebesar $14,4 \%$ dan semua aspek aktivitas mencapai kriteria aktif. Ini berarti indikator keberhasilan dalam penelitian ini sudah tercapai. Namun demikian untuk aspek menyelesaikan tugas sesuai dengan waktu yang telah ditentukan, masih perlu lebih ditingkatkan.

Beberapa faktor penyebab terjadinya peningkatan aktifitas belajar siswa dalam pembelajaran dengan menggunakan model Problem Based Instruction (PBI) adalah :

a. Guru melakukan peningkatan kualitas dalam kegiatan pendahuluan melalui media apersepsi. Dalam hal ini guru memberikan lebih banyak kesempatan siswa untuk proaktif dalam menggali kemampuan awal siswa sebagai kemampuan prasyarat yang diperlukan.

b. Guru berupaya meningkatkan kualitas motivasi dengan memberikan bimbingan dan arahan kepada setiap kelompok, khususnya untuk kelompok-kelompok yang mengalami masalah dalam menyelesaikan tugas.

c. Guru memberikan reward dalam berbagai bentuk.

Berdasarkan hasil evaluasi terkait perkembangan hasil belajar yang dicapai siswa dari siklus I ke siklus ke II yang dapat dilihat pada tabel berikut ini.

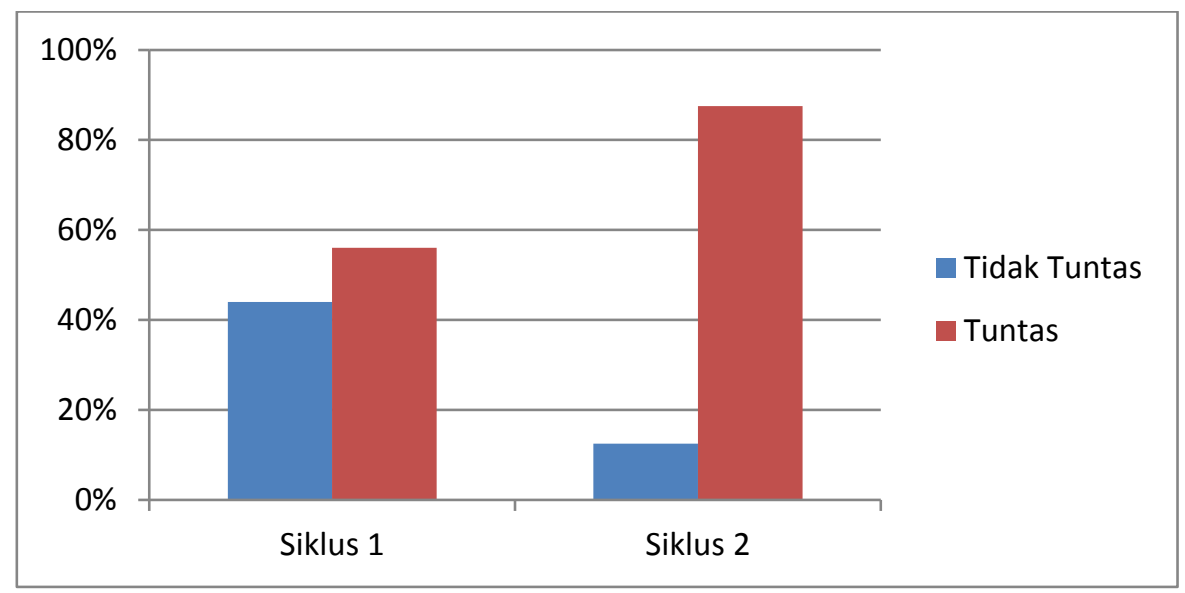

Gambar 1 : Grafik Ketuntasan Hasil Belajar Siklus I dan II 
Berdasarkan grafik perkembangan hasil belajar yang dicapai siswa di atas, menunjukkan terjadi peningkatan ketuntasan hasil belajar. Dalam hal ini dapat meningkatkan ketuntasan hasil belajar sebesar 32\%. Ini berarti indikator keberhasilan dalam penelitian ini sudah tercapai.

Beberapa faktor penyebab terjadinya peningkatan ketuntasan hasil belajar tersebut adalah.

1. Dilihat dari proses dalam hal ini adalah aktivitas belajar siswa selama pembelajaran dengan model Problem Based Instuction (PBI) berlangsung, ada peningkatan kualitas aktivitas belajar siswa dari siklus 1 ke siklus II. Aktivitas belajar siswa sangat mempengaruhi pencapaian hasil belajar siswa, hal ini disebabkan karena masalah hasil belajar adalah masalah yang komplek. Dalam hal ini banyak faktor yang mempengaruhi dan saling berkaitan antara satu faktor dengan faktor yang lainnya. Salah satu faktor yang mempengaruhi adalah aktivitas belajar siswa selama proses pembelajaran.

2. Di lihat dari perbaikan proses yaitu meningkatkan kualitas pada kegiatan pendahuluan melalui media apersepsi. Dalam hal ini guru memberikan lebih banyak kesempatan siswa untuk proaktif dalam menggali kemampuan awal siswa sebagai kemampuan prasyarat yang diperlukan, karena hasil belajar dapat dilihat dari kemampuan yang dimiliki oleh siswa setelah mendapatkan pengalaman belajar dari segi kognitif, afektif maupun psikomotor.

Proses pembelajaran dengan fase-fase yang ada pada model pembelajaran Problem Based Instruction (PBI) yaitu diawali dengan membuat kelompok belajar, pemilihan masalah, memecahkan masalah dengan penelitian, menyusun laporan hasil pemecahan masalah, mempersentasikan hasil pemecahan masalah, kelompok saling menanggapi laporan hasil pemecahan masalah, guru melakukan penguatan materi pelajaran, dan menyimpulkan materi pelajaran secara bersama-sama atas masalah yang dipecahkan sangat mampu memotivasi dan semangat belajar 
Meningkatkan Aktivitas Dan Hasil Belajar Siswa Pada Materi Barisan Dan Deret Dengan Menggunakan Model Problem Based Instruction (PBI) Di Kelas IX B SMPN 3 Paringin Tahun Pelajaran 2013/2014

siswa serta meningkatkan hasil belajar siswa, ini terbukti dari hasil peningkatan aktivitas dan hasil belajar siswa dari siklus I ke siklus II.

Hal ini terjadi juga pada penelitian yang dilakukan oleh Nisa (2011) siswa kelas IV SD yang menunjukkan bahwa model pembelajaran Problem Based Instruction (PBI) mampu meningkatkan aktivitas dan hasil belajar siswa. Pembelajaran menggunakan model pembelajaran Problem Based Instruction (PBI) ini membuat siswa lebih mudah mengerti dan memahami tentang materi barisan dan deret, karena dengan proses pembelajaran yang titik awal pembelajaran berdasarkan masalah pada kehidupan nyata dan di motivasi untuk memecahkan masalah tersebut, sangat efektif memberikan pemahaman pada konsep materi barisan dan deret, khususnya membedakan barisan aritmetika dan barisan geometri dalam soal cerita.

\section{Kesimpulan}

Berdasarkan hasil dan pembahasan yang telah ditulis sebelumnya, maka dapat dikemukakan kesimpulan sebagai berikut:

1. Model pembelajaran PBI dapat meningkatkan aktivitas belajar siswa kelas IX B SMPN 3 Paringin pada materi barisan dan deret.

2. Model pembelajaran PBI dapat meningkatkan hasil belajar siswa kelas IX B SMPN 3 Paringin pada materi barisan dan deret.

\section{Daftar Pustaka}

Arikunto, Suharsimi,dkk.2008. Penelitian Tindakan Kelas. Jakarta: Sinar grafika.

Arikunto, Suharsimi.2006. Prosedur Penelitian Suatu Pendekatan Praktik. Jakarta: PT Rineka Cipta.

Aqib, Zainal. 2009. Penelitian Tindakan Kelas untuk Guru SD, SLB dan TK. Bandung: CV. Irama Widya

Barizi, Ahmad dan Muhammad Idris. 2009. Menjadi Guru ungggul. Yogyakarta: Ar-ruzz Media.

Hamalik,Oemar. 2008. Proses Belajar Mengajar. Jakarta: Sinar Grafika. 
Ihsan, Fuad. 2010. Dasar-Dasar Kependidikan. Jakarta: Rineka Cipta.

Kunandar. 2008. Guru Langkah Mudah Penelitian Tindakan Kelas sebagai Pengembangan Profesi guru. Jakarta: PT. Raja Grafindo Persada.

Marno dan M. Idris. 2009. Strategi dan Metode Pengajaran. Jogjakarta: Ar-ruzz media.

Nisa, Choirun. 2011. Upaya Meningkatkan Hasil Belajar Siswa Materi Penjumlahan Pecahan Melalui Pembelajaran Kooperatif Tipe Problem Based Instruction (PBI) di Kelas IV SDN Pabahanan Tanah Laut. Banjarmasin: Universitas Lambung Mangkurat.

Sudijono, 2011. Pengantar Statistik Pendidikan. Jakarata: PT. Raja Grafindo Persada.

Suyatno. 2009. Menjelajah Pembelajaran Inovatif. Sidoarjo: Buana Pustaka.

Trianto.2007. Model-Model pembelajaran Inovatif Berorintasi Kunstruktivistik. Jakarta: Prestasi Pustaka.

Tim Depdiknas. 2004 .Pelayanan Profesional Kurikulum 2004 . Depdiknas, Jakarta

\section{Saudah}

Guru SMPN 3 Batumandi Kecamatan Batumandi Kabupaten Balangan

E-mail: -

\section{Agni Danaryanti}

Dosen Prodi PMTK FKIP Universitas Lambung Mangkurat

E-mail: - 